Supplementary Information:

\title{
How to improve the air quality over mega-cities in China? --- Pollution characterization and source analysis in Shanghai before, during, and after the 2010 World Expo
}

\author{
Kan Huang ${ }^{1,2}$, Guoshun Zhuang ${ }^{1, *}$, Yanfen Lin ${ }^{1}$, Qiongzhen Wang', Joshua S. Fu ${ }^{2 *}$, \\ Qingyan Fu ${ }^{3}$, Tingna Liu ${ }^{1}$, Congrui Deng ${ }^{1}$ \\ ${ }^{1}$ Center for Atmospheric Chemistry Study, Department of Environmental Science and Engineering, Fudan University, \\ Shanghai, 200433, P. R. China \\ ${ }^{2}$ Department of Civil and Environmental Engineering, The University of Tennessee, Knoxville, TN 37996, USA \\ ${ }^{3}$ Shanghai Environmental Monitoring Center, Shanghai, 200030, China \\ *Corresponding authors: G. Zhuang, \& J. S. Fu \\ E-mail address: gzhuang@,fudan.edu.cn, jsfu@utk.edu
}


Table S1. Control strategies and new implemented technology before and during the 2010 Shanghai World Expo

\begin{tabular}{|l|l|}
\hline $\begin{array}{l}\text { Industry and } \\
\text { Power Plants }\end{array}$ & $\begin{array}{l}\text { Phase out, adjust or relocation of heavily polluting industries and power plants; Design } \\
\text { special energy efficiency improvement program for major industries; Desulphurizing } \\
\text { coal-fire plants by installing flue gas desulphurization (FGD) devices; Temporary close } \\
\text { up of some factories in polluted days during the Expo. }\end{array}$ \\
\hline $\begin{array}{l}\text { Transportation } \\
\text { Upgrade and expand public transport system (developing new metro lines; establishing } \\
\text { extensive rapid transit system and network of bus lines; promoting clean energy buses } \\
\text { and taxis, etc.); Persist in the private car-license auction system to control the growth of } \\
\text { vehicle number; Upgrade the vehicle emission standards to Euro IV; Access restriction } \\
\text { of vehicles not compliant with emission standards then gradually phase out the highly } \\
\text { polluting vehicles; }\end{array}$ \\
\hline $\begin{array}{l}\text { Construction } \\
\text { Work }\end{array}$ & $\begin{array}{l}\text { Establishment of smoke and dust control zone from downtown Shanghai to suburban } \\
\text { areas; Dust-prevention measures at construction sites, requirements on the covering or } \\
\text { containment of idle soil, cement, and construction waste. }\end{array}$ \\
\hline $\begin{array}{l}\text { Household and } \\
\text { Buildings }\end{array}$ & $\begin{array}{l}\text { Energy saving project for air conditioning and other household and commercial } \\
\text { appliances; Energy efficiency renovation of existing public buildings; New energy- } \\
\text { saving architectural technology for green buildings with low energy consumption. }\end{array}$ \\
\hline $\begin{array}{l}\text { Application of } \\
\text { Technology }\end{array}$ & $\begin{array}{l}\text { Solar photovoltaic technology; River water-source/geothermal heat pump technology; } \\
\text { green building certifications; Energy-conservation air conditioning technology. }\end{array}$ \\
\hline
\end{tabular}




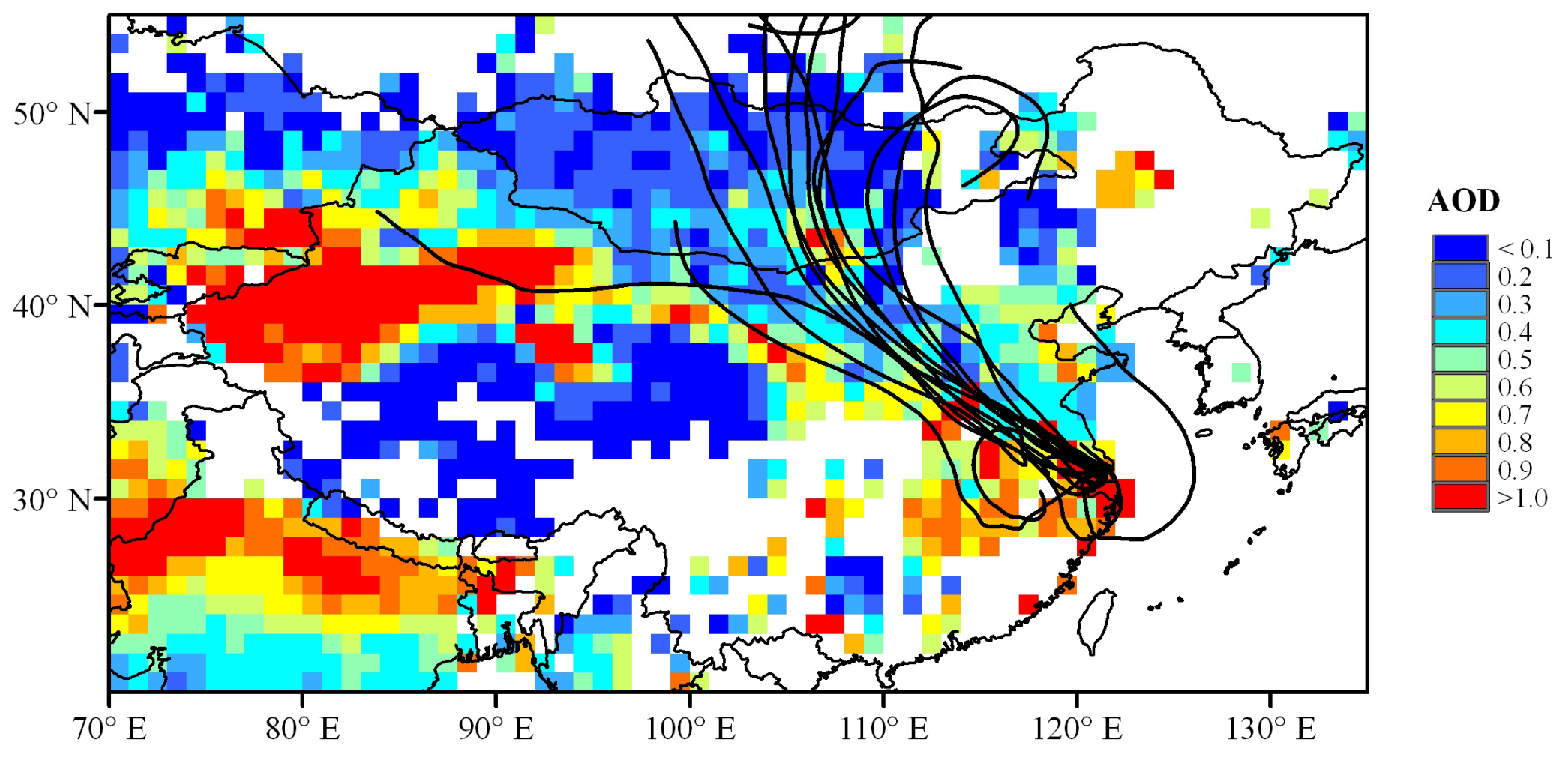

Figure S1. Three days back trajectories ending at Shanghai computed using the NOAA Hybrid Single-Particle Lagrangian Trajectory (HYSPLIT) model (R. Draxler and G. Rolph, HYSPLIT (HYbrid Single - Particle Lagrangian Integrated Trajectory) Model, 2003, http://www.arl.noaa.gov/ready/hysplit4.html) with meteorological data provided by the Global Data Assimilation System (GDAS) and the average MODIS deep blue AOD at $550 \mathrm{~nm}$ during the pre-Expo pollution episode (April 26 - 28, 2010). 


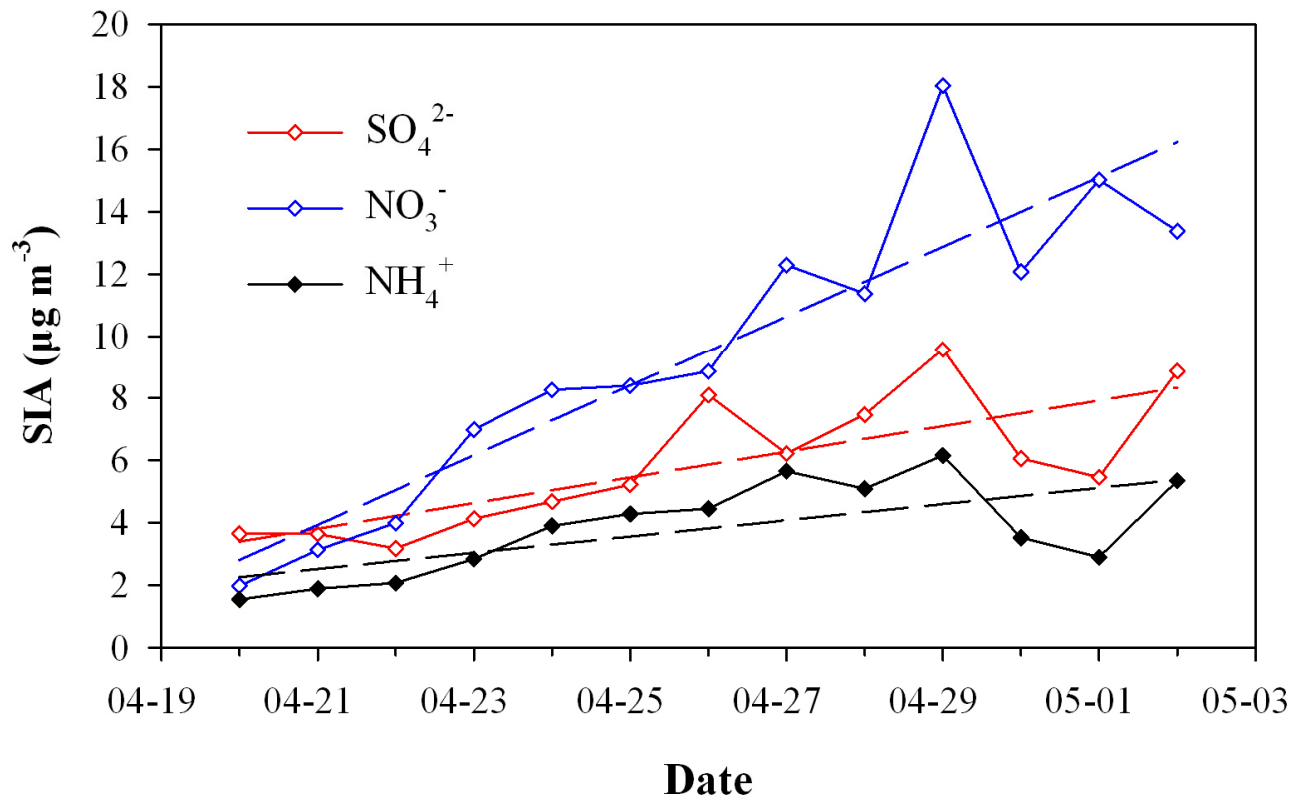

Figure S2. Daily variations of SIA $\left(\mathrm{SO}_{4}{ }^{2-}, \mathrm{NO}_{3}{ }^{-}\right.$and $\left.\mathrm{NH}_{4}{ }^{+}\right)$concentration from April 20 to May 2, 2010. Dash lines represent the linear fits for the three species, respectively. 


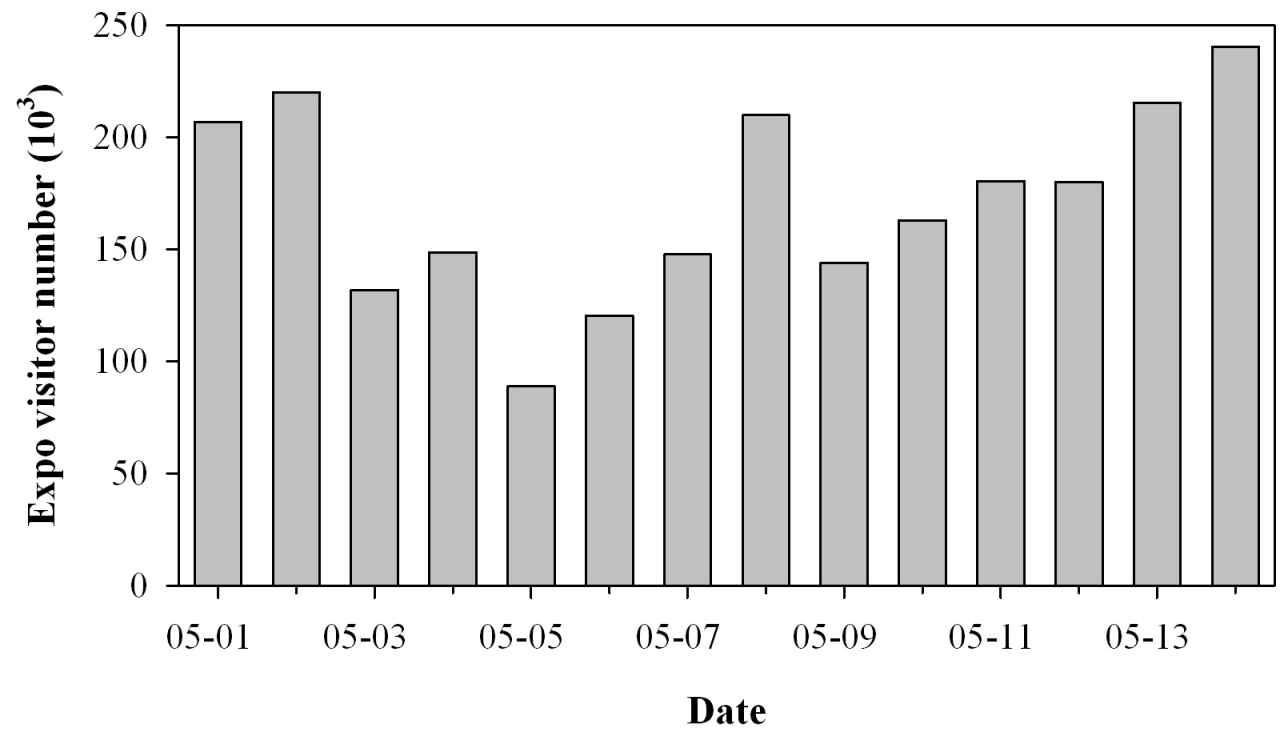

Figure S3. Daily number of the Expo visitors from May 1 to 14 . 

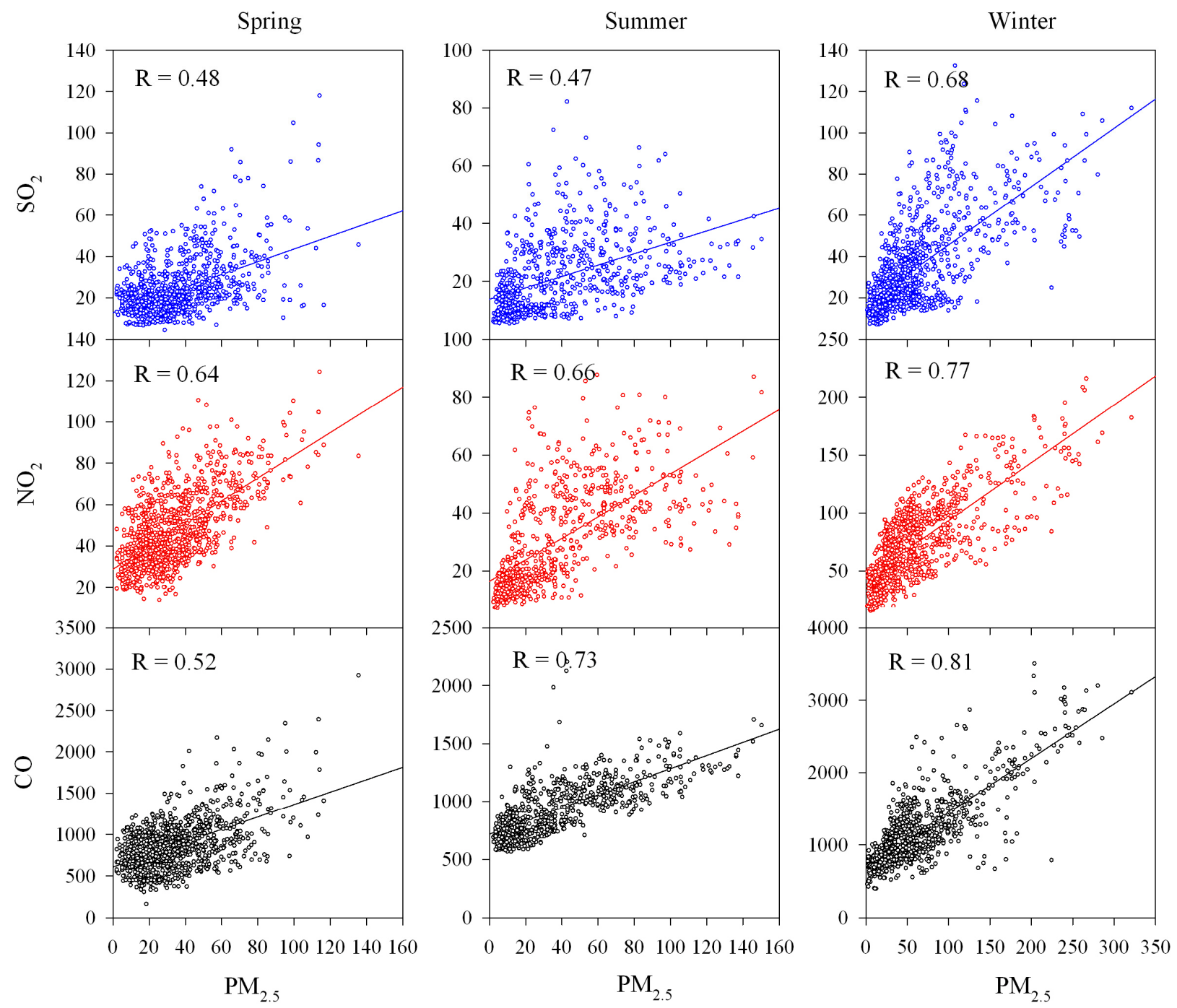

Figure S4. Linear correlations between $\mathrm{SO}_{2}, \mathrm{NO}_{2}, \mathrm{CO}$ and $\mathrm{PM}_{2.5}$ in the three seasons in 2010 , respectively. The correlation coefficients between each pair are shown in the figure. 
Jul. 28 - Aug. 4, 2010

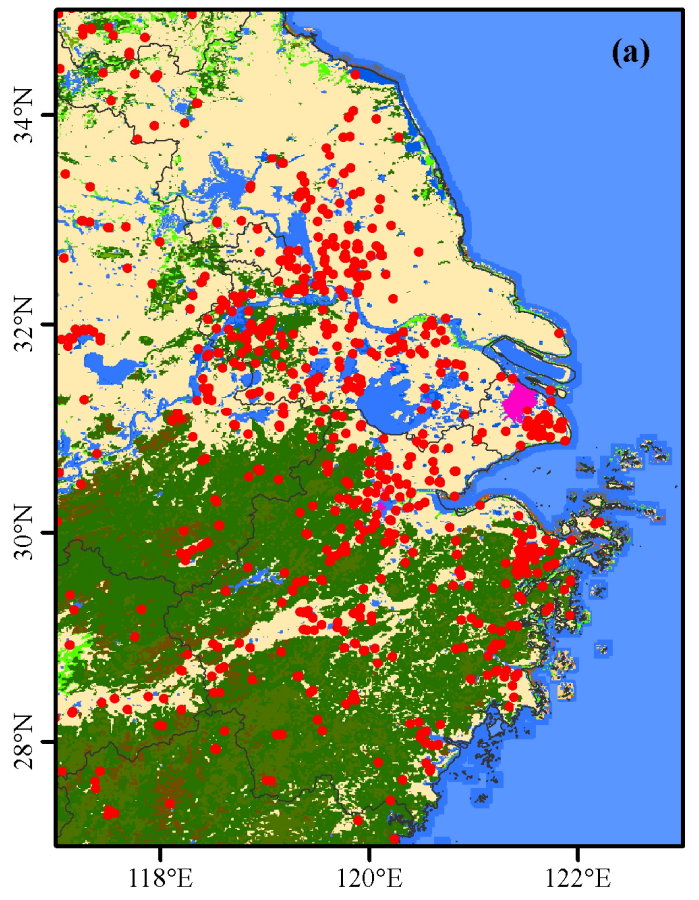

Aug. 11 to 17, 2010

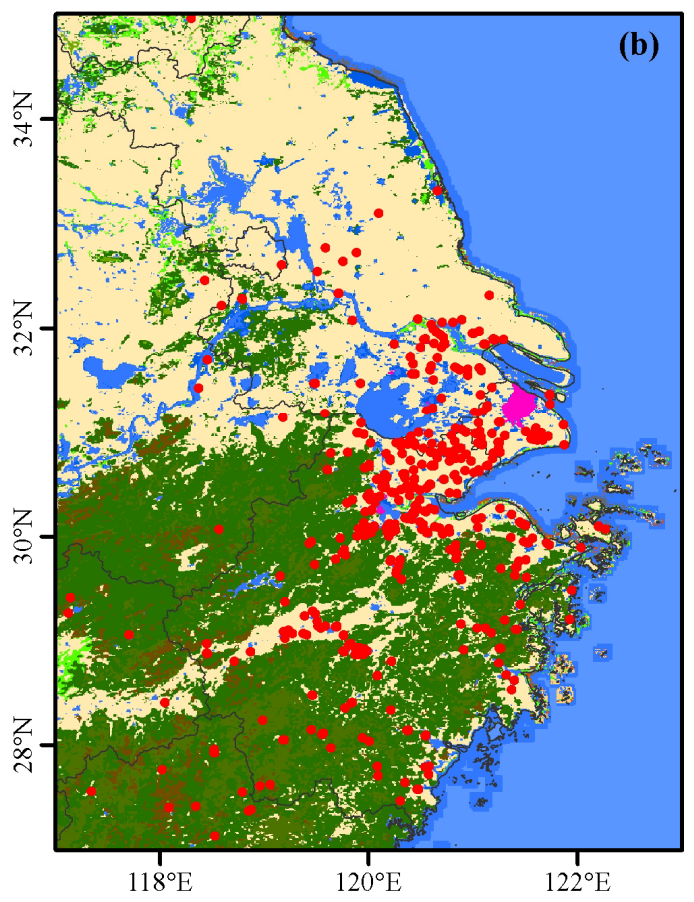

- Fire spots

Evergreen Tree Decidous tree Shrub

Cropland Water body Artificial areas

Figure S5. Fire spots (red dots) detected from MODIS during the two intense pollution episodes. Land cover types are overlaid in the figure. 


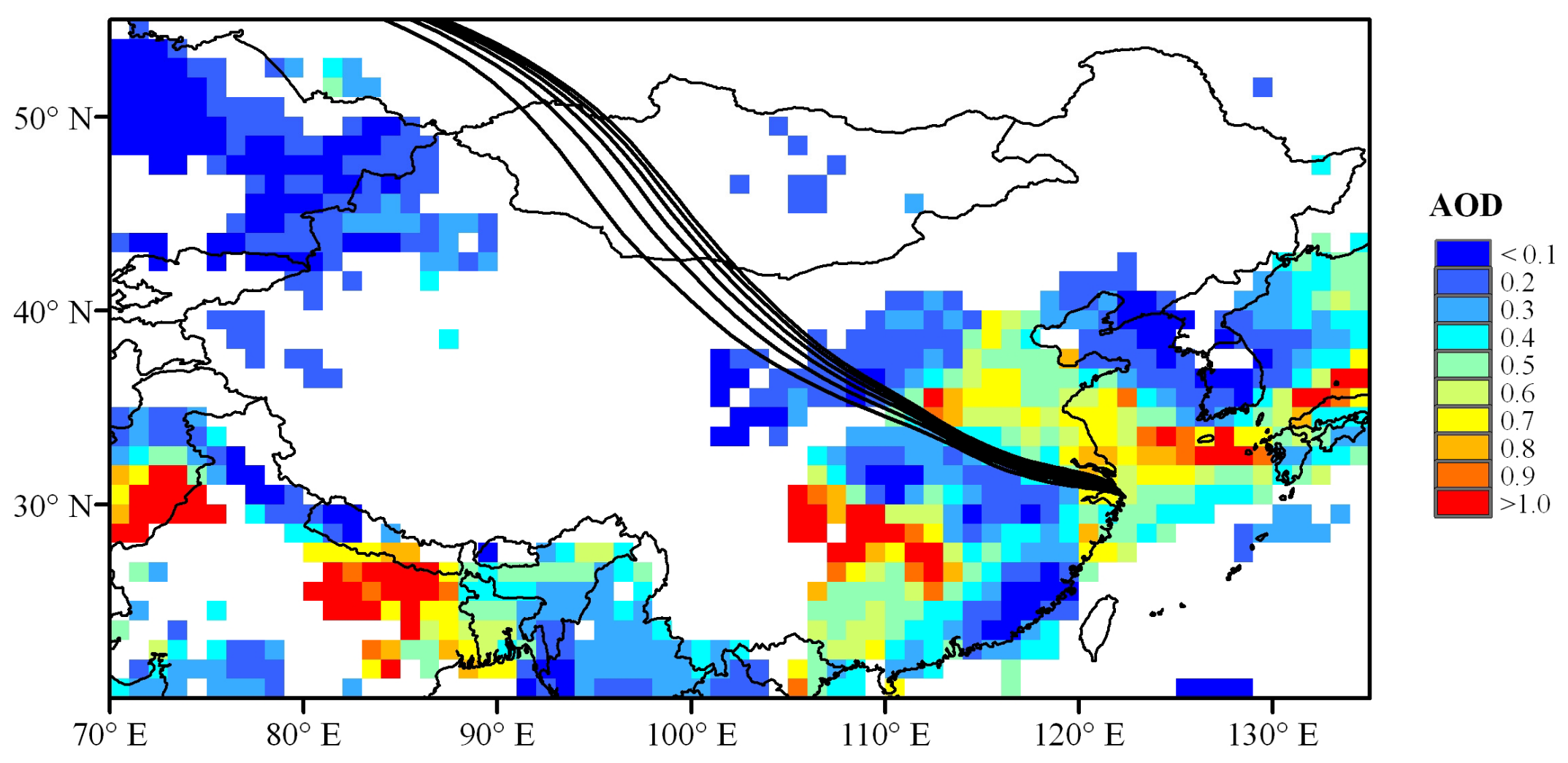

Figure S6. Same as Figure S1 but for November 12. 


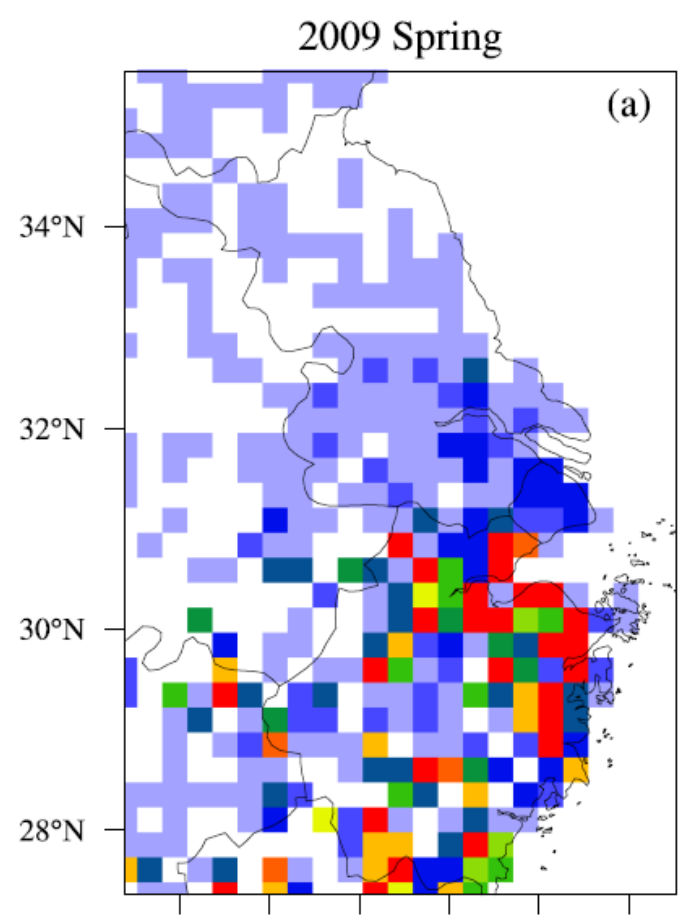

$117^{\circ} \mathrm{E} 118^{\circ} \mathrm{E} 119^{\circ} \mathrm{E} 120^{\circ} \mathrm{E} 121^{\circ} \mathrm{E} 122^{\circ} \mathrm{E}$

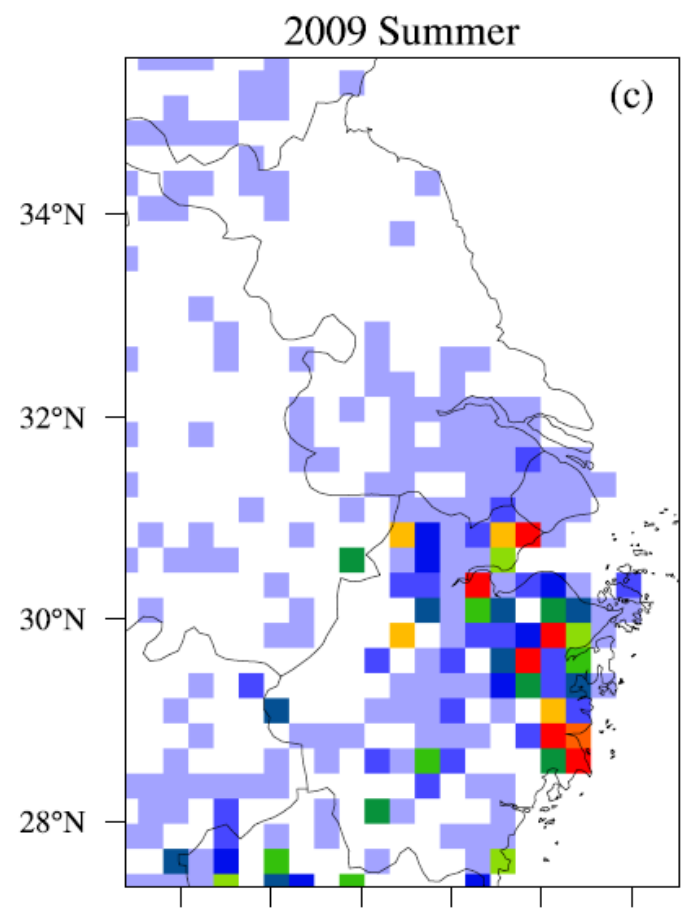

$117^{\circ} \mathrm{E} 118^{\circ} \mathrm{E} 119^{\circ} \mathrm{E} 120^{\circ} \mathrm{E} 121^{\circ} \mathrm{E} 122^{\circ} \mathrm{E}$

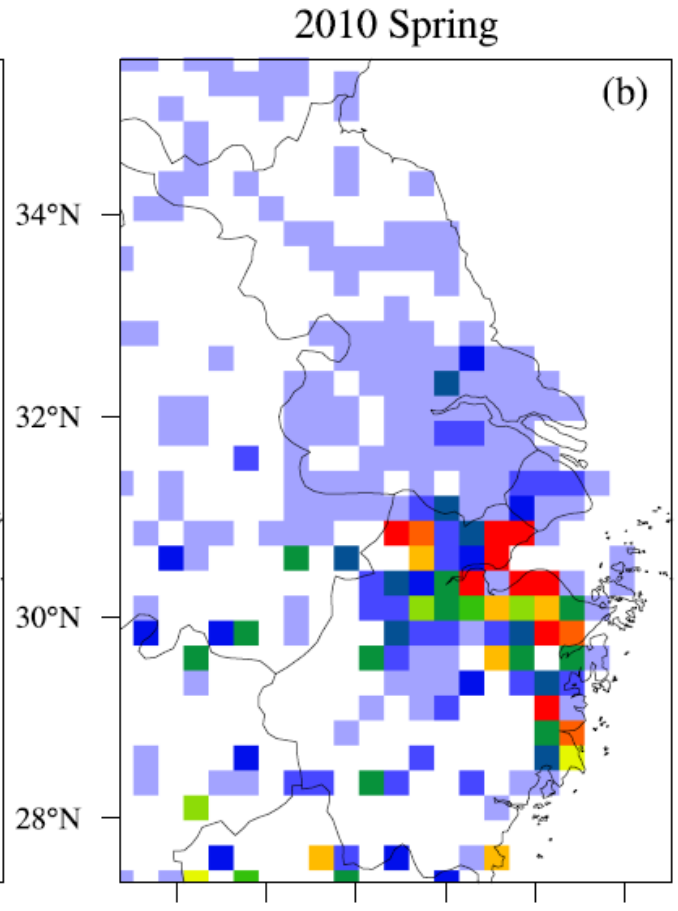

$117^{\circ} \mathrm{E} 118^{\circ} \mathrm{E} 119^{\circ} \mathrm{E} 120^{\circ} \mathrm{E} 121^{\circ} \mathrm{E} 122^{\circ} \mathrm{E}$

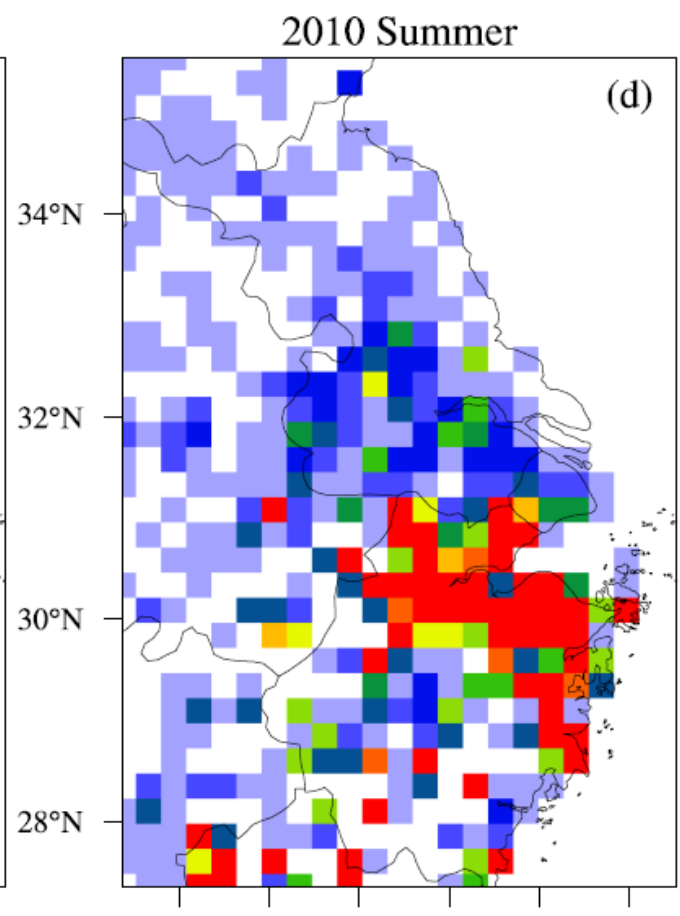

$117^{\circ} \mathrm{E} 118^{\circ} \mathrm{E} 119^{\circ} \mathrm{E} 120^{\circ} \mathrm{E} 121^{\circ} \mathrm{E} 122^{\circ} \mathrm{E}$

Figure S7. Spatial distribution of biomass burning carbon emission from FLAMBE during spring (April 2 - May 14) and summer (July 25 to August 24) in 2010 and 2009, respectively. 
(a)

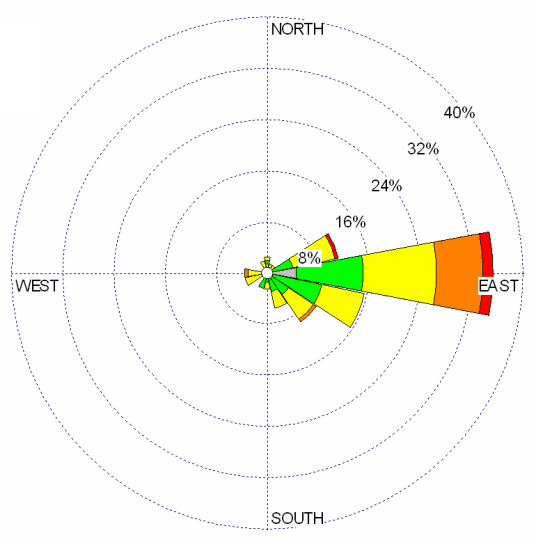

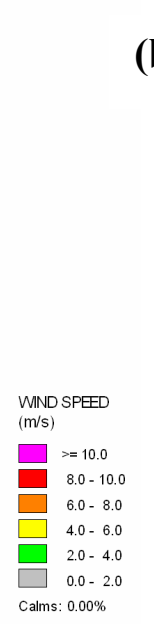

(b)

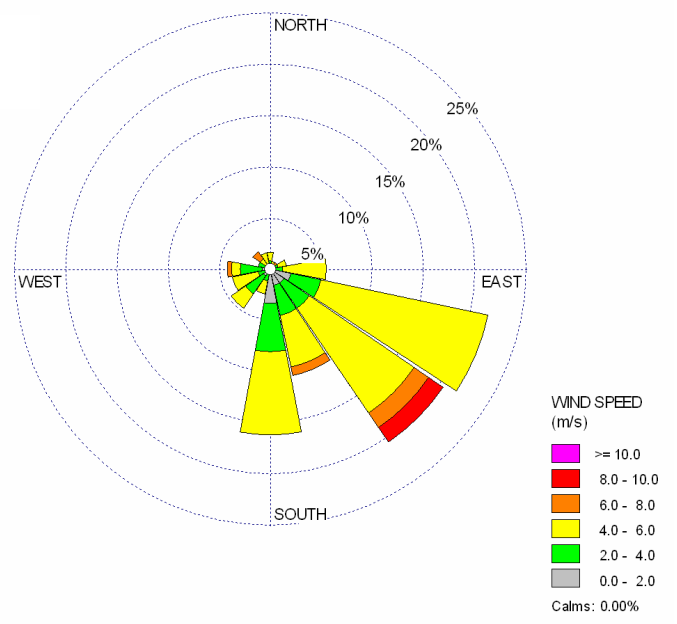

Figure S8. Wind rose plot during the summer study period (July 25 to August 24) of (a) 2009 and (b) 2010. Each circle represents the percentage of the winds from a particular direction, and different colors represent the ranges of wind speeds. 